\title{
THE EFFECT OF PROSTAGLANDIN E, ON RABBIT SPERM TRANSPORT IN VIVO
}

\author{
J. P. MANDL* \\ Department of Zoology, University of Wisconsin-Milwaukee, \\ Milwaukee, Wisconsin, U.S.A.
}

(Received 19th October 1971, accepted 21st April 1972)

\begin{abstract}
Summary. The effect of prostaglandin $\mathrm{E}_{1}\left(\mathrm{PGE}_{1}\right)$ on sperm transport in twenty-one artificially inseminated rabbits was investigated. The female genital tracts were sectioned $\frac{1}{2} \mathrm{hr}$ or $2 \mathrm{hr}$ after insemination with equivalent numbers of spermatozoa and examined for sperm transport. The inseminate used in each test animal contained $75 \mu \mathrm{g} \mathrm{PGE}_{1}$.

The average number of spermatozoa recovered from the uteri and oviducts of the test groups was greater than that of the control groups. In the group killed $\frac{1}{2} \mathrm{hr}$ after insemination, 1.8 times as many spermatozoa were recovered in the test group. Nearly 18 times as many spermatozoa on the average were recovered from the test animals killed $2 \mathrm{hr}$ after insemination. However, this was only significant for the group killed $2 \mathrm{hr}$ after insemination $(P=0.004)$. Significantly greater numbers of spermatozoa were found in the oviducts of test animals killed $2 \mathrm{hr}$ after insemination than in controls $(P=0.014)$.

This study shows that a high dose of $\mathrm{PGE}_{1}$ in seminal plasma aids sperm transport in the rabbit female genital tract.
\end{abstract}

\section{INTRODUCTION}

The greatest known mammalian concentrations of prostaglandins have been found in human seminal plasma and are absorbed intravaginally in amounts sufficient to have a marked effect on female reproductive tissues (Eliasson \& Posse, 1960, 1965; Bygdeman \& Samuelsson, 1967). Prostaglandin $\mathbf{E}_{1}\left(\mathrm{PGE}_{1}\right)$ can either inhibit or stimulate contractions of non-pregnant human uterus in vivo, and can also decrease the frequency and amplitude of rabbit uterine and Fallopian tube contractions (Horton, Main \& Thompson, 1965; Moghissi \& Murray, 1970; Coutinho \& Maia, 1971) and the spontaneous motility of the cervix (Karlson, 1959; Hiller \& Karim, 1970). These effects are most pronounced at the time of ovulation (Bygdeman, 1964).

A low prostaglandin content in semen and abnormal responses of female reproductive tissue to seminal prostaglandins have both been suspected as causes of infertility. Low PGE concentrations in semen have been correlated with infertility (Eliasson, 1959; Hawkins \& Labrum, 1961; Horton \& Thompson,

* Present address: Department of Thoracic Surgery, Walter Reed General Hospital, Washington, D.C. 20012 
1964; Bygdeman, Fredricsson, Svanborg \& Samuelsson, 1970). Eliasson \& Posse (1965) recorded an unusual increase in tubal insufflation in four infertile women 25 to $45 \mathrm{~min}$ after intravaginal deposition of prostaglandin extracts in amounts corresponding to a normal ejaculate. Bickers (1951) also reported slower sperm migration in eight of twenty-three patients with unexplained infertility. As a result of these findings, it has been suggested that PGE may enhance sperm transport, sperm capacitation, tubal retention of ova or the process of fertilization (Asplund, 1947; Horton, Main \& Thompson, 1963; Sandberg, Ingelman-Sundberg \& Ryden, 1963; Speroff \& Ramwell, 1970).

At present, however, there is little evidence for a possible mechanism whereby PGE $_{1}$ may enhance fertility. Eliasson, Murdock \& White (1968) state that PGE $_{1}$ neither increases nor decreases the maintenance of sperm activity. Hawkins \& Labrum (1961) found no correlation between the amount of prostaglandin in the semen and human sperm density or the rate of decline of sperm motility, though they did find a relationship between low prostaglandin levels and a high incidence of abnormal spermatozoa. More recently, Pento, Cenedella \& Inskeep (1970) found that prostaglandins had no effect on the carbohydrate metabolism of ejaculated ram spermatozoa. The hypothesis of Goldblatt (1935) that prostaglandins contribute to vasodilatation in the male genital tract at the time of coitus lacks support. Prostaglandin $E_{1}$ is known to inhibit contractile responses of the vas deferens, an effect which is unlikely to aid ejaculation (Holmes, Horton \& Main, 1963).

The purpose of this study was to test the hypothesis that $\mathrm{PGE}_{\mathbf{1}}$ introduced intravaginally enhances rabbit sperm transport shortly after insemination. Rabbits were used because their seminal PGE $_{1}$ concentrations are far below the threshold dosage necessary to affect the rabbit female tract (Horton et al., 1965). Therefore, determination of the effects of $\mathrm{PGE}_{1}$ on rabbit sperm transport can be made with a known amount of $\mathrm{PGE}_{1}$.

\section{MATERIALS AND METHODS}

Twenty-one mature female rabbits, most of which had produced at least one litter before experimentation, were used as subjects. The does were inseminated with semen collected from three experienced males by artificial vagina (see Macirone \& Walton, 1938). Sperm motility was checked and sperm densities determined. The pooled semen was adjusted with mammalian Ringer's solution to contain $500 \times 10^{6}$ spermatozoa $/ \mathrm{ml}$ semen.

Each doe was injected intravenously $9 \frac{1}{2}$ to $10 \mathrm{hr}$ before insemination with 75 i.u. HCG (Sigma Chem. Co., East St Louis, Ill.) so that insemination would take place at ovulation (Rowlands, 1944). A total of $75 \mu \mathrm{g} \mathrm{PGE}_{1}$ (Upjohn Co., Kalamazoo, Mich.), made up in mammalian Ringer's solution, was added to the inseminate of each female in the test groups. A corresponding volume of Ringer's solution alone was added to the inseminate of each female in the control groups. All does were inseminated with an equal number $\left(100 \times 10^{6}\right)$ of spermatozoa and an equal volume $(0.20 \mathrm{ml})$ of semen. All glassware was sterilized before use. 
The does were killed $\frac{1}{2} \mathrm{hr}$ and $2 \mathrm{hr}$ after insemination. Their genital tracts were subdivided into the following parts by ligation: the cranial half of the vagina, the cranial and caudal halves of each uterine horn, and the cranial, middle and caudal parts of each Fallopian tube. Except for the caudal half of the vagina, which was not examined, each subdivision was opened and the contents flushed into a container. The samples were coded and frozen until the numbers of intact spermatozoa could be determined with a haemocytometer.

The Mann-Whitney $U$ test was used to compare the mean numbers of spermatozoa recovered (Spence, Underwood, Duncan \& Cotton, 1968). This non-parametric test was used because of an expected large variance. Differences between means were considered significant when $P \leq 0.05$.

\section{RESULTS}

The presence of either ripened follicles or corpora haemorrhagica was taken as evidence that the ovaries of all the does were functional. Sperm densities of ejaculates before adjustment to $500 \times 10^{6} / \mathrm{ml}$ ranged from 397 to $614 \times 10^{6} / \mathrm{ml}$. More than $90 \%$ of the spermatozoa in the ejaculates from each male were motile. Thus, the bucks and does used showed no evidence of subfertility.

Insignificant differences in sperm distribution were found among the does with time. More spermatozoa were found in the cranial half of the vagina in both groups killed $\frac{1}{2} \mathrm{hr}$ after insemination than in either of the 2-hr groups (Table 1). Spermatozoa were found in the cranial third of the oviducts of the artificially inseminated animals as early as $\frac{1}{2} \mathrm{hr}$ after insemination, but the numbers of spermatozoa found in the oviducts of animals killed $\frac{1}{2} \mathrm{hr}$ and $2 \mathrm{hr}$ after insemination were not significantly different.

Greater mean numbers of spermatozoa were found in the uteri and oviducts of does inseminated with PGE $_{1}$. In the group killed $\frac{1}{2} \mathrm{hr}$ after insemination, an average of 1.8 times more spermatozoa were recovered from the test females (Table 1). In the group killed $2 \mathrm{hr}$ after insemination, an average of nearly 18 times as many spermatozoa were recovered from the oviducts and uteri of test females. However, due to the large variations in numbers of individual animals, the results were statistically significant only for the 2-hr group $(P=0.004)$.

Significantly greater mean numbers of spermatozoa were found in each subdivision of the oviducts of test animals killed $2 \mathrm{hr}$ after insemination (Table 1 ).

\section{DISCUSSION}

Prostaglandins have been found in the seminal fluid of man, sheep, goat and rabbit. The site of sperm deposition during coitus in these animals is the vagina. However, prostaglandins have not been found in the seminal fluid of the horse, mouse and pig in which spermatozoa are deposited in the uterus. The rôle of $\mathrm{PGE}_{1}$ in aiding sperm transport in species which deposit semen intravaginally does not appear to have been previously tested.

Greater mean numbers of spermatozoa cranial to the cervix were observed in PGE $_{1}$-treated animals. The mechanism by which PGE $_{1}$ caused this effect is unknown. However, $\mathrm{PGE}_{1}$ inhibits smooth muscle tone in all parts of the 


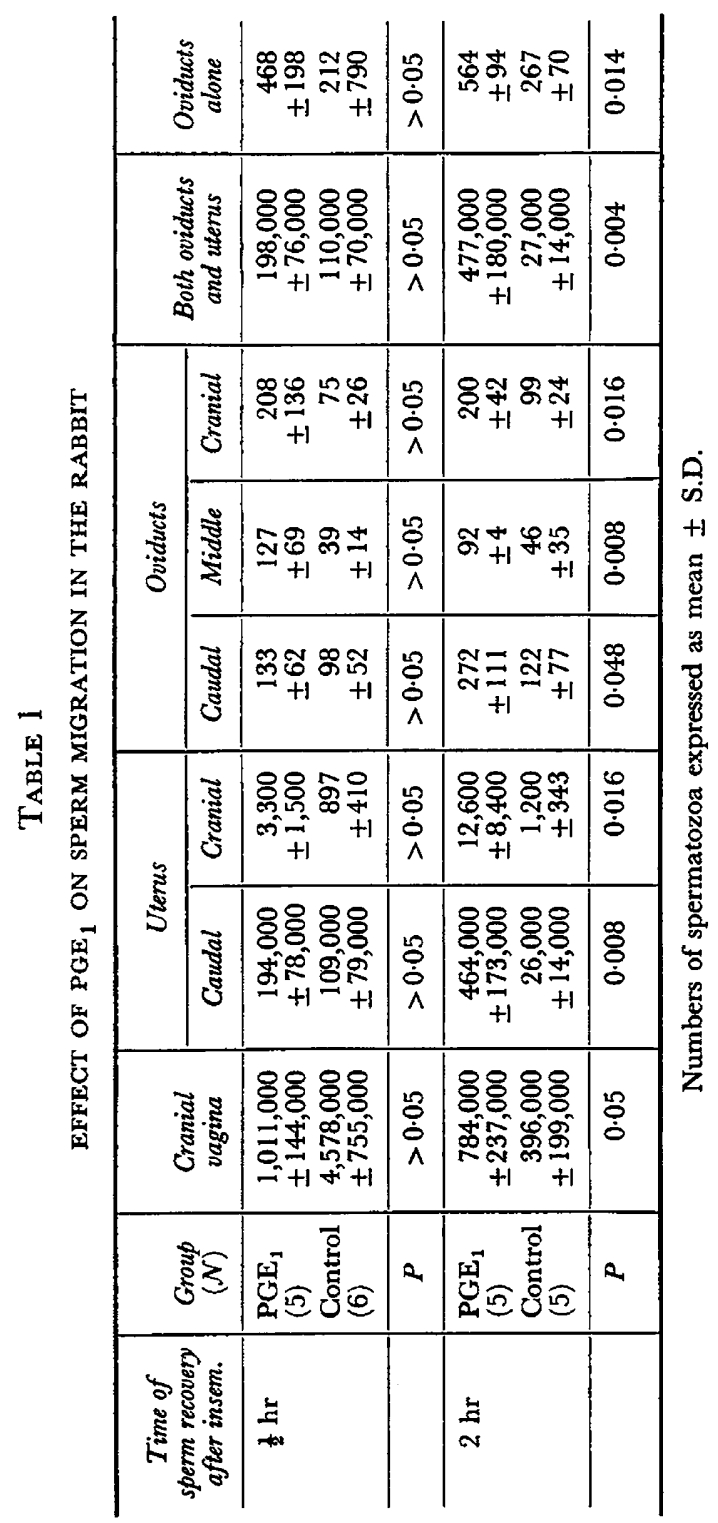


female rabbit reproductive tract and causes a fall in intraluminal pressure in the oviducts (Horton et al., 1965). Prostaglandin $\mathrm{E}_{1}$ in humans, as in the rabbit, reduces spontaneous motility of uterine and cervical muscles (Karlson, 1959; Eliasson \& Posse, 1960). Prostaglandin $E_{1}$ also stimulates the contraction of the caudal part of the Fallopian tube (Sandberg et al., 1963). Thus, a suction effect could be created by the inhibition of uterine activity and the stimulation of the caudal portion of the oviduct (Eliasson \& Posse, 1965). A suction effect has been observed during artificial insemination in women (Hartman, 1957), though the same effect may not occur in rabbits. Intravenous injections of $\mathrm{PGE}_{1}$ caused a relaxation in vivo of the isthmic circular muscles and reduced the intraluminal pressure in the oviduct (Horton et al., 1963). An alternative mechanism by which $\mathrm{PGE}_{1}$ could enhance sperm transport might be a coordinated movement of the genital tract musculature, including relaxation of the cervix. This might allow greater numbers of spermatozoa to pass into the uterus.

In this study, significantly greater average numbers of spermatozoa were found $2 \mathrm{hr}$ after insemination in the oviducts of $\mathrm{PGE}_{1}$-treated animals. The present data do not indicate whether the greater numbers were due to the presence of more spermatozoa in the uteri or to effects of $\mathrm{PGE}_{1}$ on the uterotubal junction or oviducts. Since $\mathrm{PGE}_{1}$ reduces the oviduct intraluminal pressure in rabbits (Horton et al., 1965), spermatozoa may pass the uterotubal barrier more easily.

Spermatozoa were found in rabbit oviducts $\frac{1}{2} \mathrm{hr}$ after insemination, the earliest that spermatozoa have been reported in the rabbit oviduct. Braden (1953) recovered spermatozoa from the lower portions of the oviducts $3 \mathrm{hr}$ after mating. Chang (1952) and Adams (1956) reported the presence of spermatozoa in the oviduct $1 \mathrm{hr}$ after mating. In all of the foregoing studies, however, the does were mated naturally rather than artificially and at ovulation rather than $10 \mathrm{hr}$ before ovulation.

It seems doubtful if PGE has a physiological rôle in rabbit or sheep sperm transport. The prostaglandin level in the rabbit is less than $0.05 \mu \mathrm{g} /$ ejaculate, which is less than the intravaginal concentration necessary to produce detectable effects on the rabbit female tract (Horton \& Thompson, 1964). In this study, $75 \mu \mathrm{g} \mathrm{PGE}_{1}$ was used. Likewise, the intravaginal threshold dose for an effect in the sheep oviduct was four times the total prostaglandin content of a single ram ejaculate (Horton et al., 1965). In human sperm transport, however, the rôle of $\mathrm{PGE}_{1}$ may be important as the seminal prostaglandin levels average 200 $\mu \mathrm{g} / \mathrm{ml}$ (Bygdeman, Hamberg \& Samuelsson, 1966).

This study shows that a high dose of $\mathrm{PGE}_{1}$ in semen facilitates sperm transport in the rabbit female reproductive tract. The significance of this action of $\mathrm{PGE}_{1}$ in other species, particularly those with naturally high concentrations of seminal prostaglandins, remains to be studied.

\section{ACKNOWLEDGMENTS}

The author wishes to thank Dr E. D. Warner, Dr J. E. Minnich, Dr N. Press, and $\mathrm{Dr} \mathrm{J}$. Anthony for their criticisms and comments; the Upjohn Company 
for their donation of $\mathrm{PGE}_{1}$; and Capt H. Dickson, Ph.D., and Capt J. Wiorkowski, Ph.D., United States Army Medical Field Service School, for their statistical advice.

\section{REFERENCES}

Adams, C. E. (1956) A study of fertilization in the rabbit: the effect of post-coital ligation of the Fallopian tube or uterine horn. F. Endocr. 13, 296.

Asplund, J. (1947) A quantitative determination of the content of contractive substances in human sperm and their significance for the motility and vitality of the spermatozoa. Acta physiol. scand. $13,103$.

Bickers, W. (1951) Patterns of uterine motility in relation to spermigration. Fert. Steril. 2, 342.

Braden, A. W. (1953) Distribution of sperms in the genital tract of the female rabbit after coitus. Aust. 7. biol. Sci. 6, 693.

Bygdeman, M. (1964) The effect of different prostaglandins on the human myometrium in vitro. Acta physiol. scand. 63, Suppl. 242, 1.

Bygdeman, M., Fredricsson, B., Svanborg, K. \& Samuelsson, B. (1970) The relation between fertility and prostaglandin content of seminal fluid in man. Fert. Steril. 21, 622.

Bygdeman, M., Hamberg, M. \& Samuelsson, B. (1966) The content of different prostaglandins in human seminal fluid and their threshold doses on the human myometrium. Mem. Soc. Endocr. 14, 49.

Bygdeman, M. \& Samuelsson, B. (1967) Prostaglandins in human seminal plasma and their effects on human myometrium. Int. $\mathcal{F}$. Fert. $12,17$.

Chang, M. C. (1952) Fertilizability of rabbit ova and the effects of temperature in vitro on their subsequent fertilization and activation in vivo. J. exp. Zool. 121, 351.

CoutinHo, E. M. \& MAIA, H. S. (1971) The contractile response of the human uterus, Fallopian tubes, and ovary to prostaglandins in vivo. Fert. Steril. 22, 539.

Eliasson, R. (1959) Studies on prostaglandin. Occurrences, formation and biological actions. Acta physiol. scand. 46, Suppl. 158, 1.

Eliasson, R., Murdock, R. N. \& White, I. G. (1968) The metabolism of human spermatozoa in the presence of prostaglandin $\mathrm{E}_{1}$. Acta physiol. scand. 73, 379 .

Eliasson, R. \& Posse, N. (1960) The effect of prostaglandin on the non-pregnant human uterus in vivo. Acta obstet. gynec. scand. 39, 112.

Eliasson, R. \& Posse, N. (1965) Rubin's test before and after intravaginal application of prostaglandin. Int. F. Fert. 10, 373.

Goldblatt, M. W. (1935) Properties of human seminal plasma. 7. Physiol., Lond. 84, 208.

Hartman, C. G. (1957) How do sperms get into the uterus? Fert. Steril. 8, 403.

Hawkins, D. F. \& Labrum, A. H. (1961) Semen prostaglandin levels in fifty patients attending a fertility clinic. F. Reprod. Fert. 2, 1.

HiLleR, K. \& KarIM, S. M. (1970) The human isolated cervix: a study of its spontaneous motility and responsiveness to drugs. Br. J. Pharmac. Chemother. 40, 576P.

Holmes, S. W., Horton, E. W. \& MAIN, I. H. M. (1963) The effect of prostaglandin $E_{1}$ on responses of smooth muscle to catecholamines, angiotensin and vasopressin. Br. F. Pharmac. Chemother. 21, 538.

Horton, E. W., Main, I. H. M. \& Thompson, C. J. (1963) The action of intravaginal prostaglandin $\mathrm{E}_{1}$ on the female reproductive tract. 7 . Physiol., Lond. 168, 54P.

Horton, E. W., Main, I. H. M. \& Thompson, C. J. (1965) Effects of prostaglandins on the oviduct, studied in rabbits and ewes. F. Physiol., Lond. 180, 514.

Horton, E. W. \& THOMPSON, C. J. (1964) Thin-layer chromatography and bio-assay of prostaglandins in extracts of semen and tissues of the male reproductive tract. Br. F. Pharmac. Chemother. 22, 183.

Karlson, S. (1959) The influence of seminal fluid on the motility of the non-pregnant human uterus. Acta obstet. gynec. scand. 38, 503.

Macirone, C. \& Walton, A. (1938) Fecundity of male rabbits as determined by dummy matings. $\mathcal{f}$. agric. Sci., Camb. 28, 122.

Moghissi, K. S. \& MURRAY, C. P. (1970) The function of prostaglandins in reproduction. Obstetl. gynec. Surv. 25, 281.

Pento, J. T., Genedella, R. J. \& Inskeep, E. K. (1970) Effects of prostaglandins E $_{1}$ and $F_{1 a}$ upon carbohydrate metabolism of ejaculated and epididymal ram spermatozoa in vitro. F. Anim. Sci. 30, 409.

Rowlands, I. W. (1944) Capacity of hyaluronidase to increase the fertilizing power of sperm. Nature, Lond. 154, 332. 
Sandberg, F., Ingelman-Sundberg, A. \& Ryden, G. (1963) The effect of purified prostaglandin $\mathrm{E}_{1}$ on the human uterus and tubes. Int. F. Fert. 8, 869.

Spence, J. T., Underwood, B. J., Duncan, C. P. \& Cotton, J. W. (1968) Elementary statistics, p. 211. Appleton-Century-Crofts, New York.

Speroff, L. \& Ramwell, P. W. (1970) Prostaglandins in reproductive physiology. Am. 7. Obstet, Gynec. 107, 1111. 